\title{
Accelerating expansion
}

\section{ERIK SONTHEIMER}

RNA Therapeutics Institute, Program in Molecular Medicine, University of Massachusetts Medical School, Worcester, Massachusetts 01605, USA

Given the day-to-day demands and busy-ness of scientific research and academic life, it is all too easy to forget the benefits of stepping back from time to time to consider the state of our chosen field and how it has progressed over a time span of decades. When I first received Tim Nilsen's request for this piece - which at first I reflexively added to my mental ledger of day-to-day demands! - I did not realize how satisfying it would be to consider how much we have learned across the entire expanse of the RNA field.

I write as someone who, as of the publication of RNA's inaugural issue in March 1995, was still in the early phases of postdoctoral research. It felt to me then, given all of the RNA science that I had just been taught as a graduate student, like we knew a lot. And I suppose that in some ways we did! But when considering the universe of RNAs that were unknown or barely glimpsed at that time, and the cellular roles that they fill and the mechanisms that they employ, it's obvious that I had no idea. The first (and, in March 1995, still the only) microRNA had recently been revealed, and we knew essentially nothing of siRNAs, piRNAs, lncRNAs, crRNAs, circRNAs, etc., etc., etc. And of course, even our established friends (e.g., tRNAs, mRNAs, rRNAs, snRNAs, snoRNAs) had many, many sides to their person- alities that they had not yet disclosed. Only a tiny smattering of bacterial and archaeal genome sequences were in hand, the number of complete eukaryotic genome sequences was precisely zero, and RNA molecules were still nearly always identified and sequenced one at a time. As the readers of this journal know well, today the situation is...um...different. And as the accelerating expansion of the RNA universe proceeds, so do the opportunities for mechanistic insight, methodological advancement, and disease treatment. It has been a joy to see so much of it play out in this, the journal of the RNA Society. For so many of us, this Society, its annual meeting, and its journal are truly an intellectual home.

Although it would be easy and natural to consider the past 20 years from a triumphalist vantage point, a healthier posture would be one of humility. Once again, it is easy to feel like we know a tremendous amount. But once again it is safe to assume that our 2015 understanding of the RNA world will look far more meager (or so we should hope!) when we write our 2035 retrospectives. Given the momentum that Tim has helped us all build up over the last 20 years, I trust that we will again get the opportunity to write those retrospectives in the pages of RNA.
Corresponding author: erik.sontheimer@umassmed.edu

Article and publication date are at http://www.rnajournal.org/cgi/doi/10. 1261/rna.050682.115. Freely available online through the RNA Open Access option.
(C) 2015 Sontheimer This article, published in $R N A$, is available under a Creative Commons License (Attribution-NonCommercial 4.0 International), as described at http://creativecommons.org/licenses/by-nc/4.0/. 

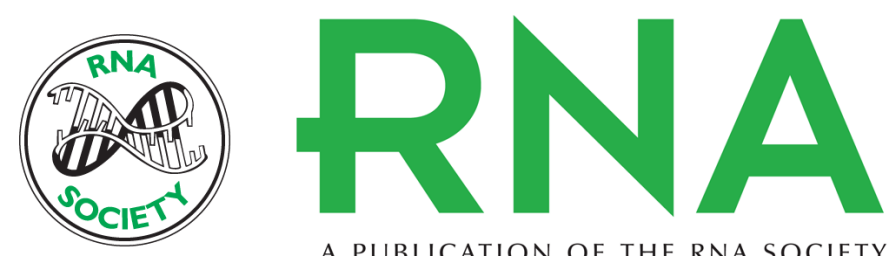

A PUBLICATION OF THE RNA SOCIETY

\section{Accelerating expansion}

Erik Sontheimer

RNA $201521: 510$

Open Access Freely available online through the RNA Open Access option.

Creative This article, published in $R N A$, is available under a Creative Commons License

Commons (Attribution-NonCommercial 4.0 International), as described at

License http://creativecommons.org/licenses/by-nc/4.0/.

Email Alerting Receive free email alerts when new articles cite this article - sign up in the box at the Service top right corner of the article or click here.

To subscribe to $R N A$ go to:

http://rnajournal.cshlp.org/subscriptions

(C) 2015 Sontheimer; Published by Cold Spring Harbor Laboratory Press for the RNA Society 